\title{
TENSÕES NO ENSINO DO BALÉ CLÁSSICO: NOTAS ETNOGRÁFICAS
}

\section{TENSIONS IN THE TEACHING OF CLASSICAL BALLET: ETHNOGRAPHIC NOTES}

\section{Fernanda Ferreira de Abreu}

fernandafabreu@gmail.com

Doutora em Antropologia Social pela Universidade Federal do Rio de Janeiro. Professora Adjunta do

Departamento de Comunicação Social da Universidade Federal Fluminense.

\section{RESUMO}

Este artigo é resultado de trabalho de campo realizado numa academia de dança de Niterói (RJ) por meio de "participação observante" e entrevistas com professoras de balé clássico. Visa apresentar as dinâmicas de sociabilidade que se produzem nesse espaço, geralmente ofuscado por contextos profissionais, apesar de ser a principal alternativa das pessoas que trabalham com o balé clássico ou fazem aula dessa modalidade de dança. Busca-se compreender como os termos disciplina e descontração são acionados e colocadosem relação em um contexto de ensino que não tem por objetivo a formação de bailarinos clássicos profissionais, o que é analisado à luz da "tensão entre iluminismo e romantismo" na cultura ocidental moderna.

Palavras-chave: Balé clássico. Academia de dança. Etnografia.

\begin{abstract}
This paper is the result of fieldwork conducted at a dance academy in Niterói (RJ) through "observant participation" and interviews with classical ballet teachers. It aims to present the dynamics of sociability that take place in this space, usually overshadowed by professional contexts, although it is the main alternative of people who work with classical ballet or take classes in this dance mode. It seeks to understand how the terms discipline and relaxation are triggered and placed in relation in a context of teaching that does not aim to produce classical professional dancers. That is analyzed in the light of the "tension between enlightenment and romanticism" in modern western culture.
\end{abstract}

Keywords: Classical ballet. Dance academy. Ethnography.

\section{INTRODUÇÃO}

Para a pesquisa de campo vinculada a meu projeto de doutorado sobre carreiras no ensino do balé clássico (ABREU, 2016), parti do contato que tinha com professoras de uma academia de dança da qual sou aluna: a Escola de Dança Myriam Camargo, localizada em Niterói (RJ), onde me iniciei no balé em 1998, aos 16 anos $^{1}$. Minha ideia inicial, numa tentativa de me ajudar a 
estranhar as aulas de balé que me eram familiares (DAMATTA, 1978), foi me matricular na Escola Estadual de Dança Maria Olenewa, vinculada ao Theatro Municipal do Rio de Janeiro e pioneira no Brasil na formação de bailarinos clássicos profissionais, além deuma importante referência até os dias atuais. Cheguei a frequentar durante cinco meses umcurso livre intermediário, que é feito como reforço por alunas do curso profissionalizante, com idades entre 11 e 16 anos, e também por alunas de fora, geralmente mais velhas, o que era o meu caso.As aulas da formação profissionalizante são gratuitas, mas os alunos são selecionados mediante uma prova rigorosa e concorrida - na qual se avaliam sobretudo ascondições físicas -, e precisam ter entre 8 e 21 anos de idade. Já para fazer oscursos livres, basta pagar uma mensalidade 2 .

Após constatar que, de modo geral, as etnografias do balé clássico, seja no Brasil ou em âmbito internacional (HOPPE, 2000; MORA, 2010; RUIZ, 2010; WULFF, 1998), tiveram por objeto bailarinas e bailarinos profissionais ou em vias de profissionalização, comecei a pensar em partir de minha própria experiência como aluna de academia de dança de Niterói, com o intuito de analisar outra forma de vivência, normalmente invisibilizada, apesar de ser a principal alternativa das pessoas que trabalham com o balé clássico ou fazem aula desta modalidade de dança.

Ainda que a minha posição de aluna anterior e simultânea à de pesquisadora não possa ser explorada a fundo no presente texto - tendo sido discutida em outro artigo (ABREU, 2015) -, considero fundamental indicar que os dados por mim construídos se inseremnum contexto de experiência partilhada.O trabalho de campo, iniciado em 2013, foi realizadopor meio de entrevistas individuais com professoras de diferentes idades e em variados estágios da carreira; além de "participação observante" (WACQUANT, 2002) na turma adiantada da Escola de Dança Myriam Camargo (doravante citada como EDMC), o que me propiciou um contato contínuo, durante três anos, com as professoras de balé que eram alunas desta turma, e cujas idades variavam de 20 a 40 anos. Essas aulas, que tiveram em média doze alunas, não eram frequentadas somente por professoras da EDMC; algumas tinham, inclusive, suas próprias academias de dança, mas lá continuavam fazendo aula para manterem o preparo físico, além de adquirirem ideias para suas próprias aulas. Ainda que a maioria das alunas dessa turma fosse também professora, esse não era o caso da totalidade, no que me incluo. Cabe sinalizar que a EDMCtambém oferece aulas de jazze sapateado, e conta com nove professoras - incluindo sua proprietária -, sendo sete de balé clássico. Estas, assim como suas alunas - todas mulheres -, são, em sua grande maioria, das camadas médias.

O objetivo deste artigo consisteemapresentar e analisar - tendo como foco as aulas da turma adiantada de balé clássico, e as professoras da EDMC que a frequentam -a sociabilidade que se produzna academia de dança. Ao mesmo tempo que as aulas geralmente ocorrem num clima descontraído,enfatiza-se a realização de um trabalho sério, especialmente no caso do balé clássico, para cujo ensino considera-se fundamental impor disciplina. Essa combinação entre disciplina e descontração - em diálogo com outros pares correlatos, como trabalho e lazer, dor e prazer, técnica e emoção - é pensada à luz da "inarredável tensão entre iluminismo e romantismo" na cultura ocidental moderna (DUARTE, 2006); e aponta para uma combinação específica, diferenciando-se de contextos profissionalizantes do ensino do balé, que serão eventualmente evocados ao longo do texto. 


\title{
DISCIPLINA E DESCONTRAÇÃO
}

\begin{abstract}
Hoje uma moça que parecia ter em torno de 20 anos foi fazer aula conosco na EDMC. Como de costume, houve risos, brincadeiras e piadas entre as alunas, de algumas das quais a professora da turma e dona da academia, Myriam, também participou. Talvez preocupada com a imagem que esta nova aluna teria de sua academia, ela fez questão de explicar: 'A gente brinca. Mas nosso trabalho é sério. É porque somos uma família. Todas estão aqui desde a década de 90 [a academia foi fundada em 1982]. Uma é madrinha de casamento da outra. Se não foi, ainda vai ser. Por isso a aula é toda assim nesse clima descontraído. [Nota de 27 de junho de 2014].
\end{abstract}

Antes do início da aula da turma adiantada, todas conversavam, como normalmente acontece. Desta vez, o assunto girou em torno dos maridos e namorados. Uma aluna disse que com seu marido foi tratamento de choque: com apenas quatro meses de namoro, ele viajou com duas de suas amigas do balé. "Tem que ser assim mesmo" - enfatizou Myriam. - "Eles têm que se adaptar. Somos um grupo muito fechado". Uma aluna [nessa aula, a única que era somente aluna - e não professo$\mathrm{ra}-$, além de mim] questionou: 'Mas é assim no balé?'. 'Falo do nosso grupo' - respondeu Myriam. [Nota de 9 de agosto de 2013].

De fato, pude vivenciar como esse grupo é fechado, ao ter parado as aulas de balé em 2002 e só ter retornado para a EDMC dez anos depois. Especialmente numa aula, senti-me muito deslocada, pois só se comentava sobre o aniversário de uma das meninas da turma, que havia sido na véspera e para o qual somente eu não havia sido convidada. O que é compreensível, pois não eram apenas suas colegas de turma, mas suas amigas de longa data, e algumas eram suas melhores amigas. É comum que as alunasdesta turma adiantadapostem em redes sociais na internet fotos delas juntas em passeios, festas e reuniões em suas casas com legendas como: "Amigas do balé são amigas para a vida toda"; "A melhor família que poderíamos escolher".

A professora responsável pelas turmas de baby(meninas entre 3 e 4 anos de idade) e também aluna da turma adiantada, Juliana, enfatizou que as crianças pequenas são o carro-chefe da academia:"Conseguindo manter essas crianças, elas vão ficar aqui dançando. Não é para vir simplesmente me imitar e ir embora. Tem que criar vínculo, tem que gostar de estar aqui". Juliana entrou na EDMC em 1994, com 11 anos. A categoria família é acionada em seu discurso para se referir às suas alunas: "Sempre falei que elas são minhas filhas, mesmo antes de engravidar. 'Eu já tenho filhos'. Porque é como se fosse; eu tenho muito carinho por elas"; como para descrever sua relação com a diretora da academia: "Myriam também é uma mãe. Ela diz que podia ser minha mãe, é 20 anos mais velha que eu. Me chama às vezes de filhinha, me puxa a orelha também". As alunas são consideradas filhas. Porém, as mães pagam uma mensalidade para que essa relação possa se produzir. É preciso atentar, desse modo, para o fato de que essas relações que supostamente constroem uma família estão perpassadas por uma lógica mercadológica. A academia, como qualquer empresa, depende da atração de novos clientes e manutenção dos atuais para se perpetuar; e a construção de relações de família estabelece laços mais difíceis de serem rompidos, o que, por sua vez, favorece a sobrevivência da empresa. É diferente do caso do curso profissionalizanteda Escola Estadual de Dança Maria Olenewa (EEDMO), que é mantido com verba governamental, e cujos alunos não pagam uma mensalidade.

A quantidade de alunas da EDMC (aproximadamente 400) permite que suas professoras trabalhem exclusivamente lá. Elas mostraram-se satisfeitas 
com a remuneração recebida - sem que eu as indagasse a esse respeito -, que é calculada a partir de um porcentual da mensalidade paga por suas alunas. $\mathrm{O}$ tempo de permanência também pode ser um indicador desse contentamento. Desde 1998, quando entrei na academia, só soube de quatro professoras de balé que saíram: duas devido à mudança de trabalho de seus maridos para outro país ou estado; uma para se dedicar mais à sua família; e outra para se aposentar. Nenhuma se afastou para lecionar em outras academias de dança próximas geograficamente.

Praticamente todas foram alunas de Myriam, a maioria desde a infância ou início da adolescência. Devido a essa baixa rotatividade, é difícil vir a compor esse quadro de professoras. Conversei com uma ex-aluna da EDMC que disse ter ido para academias da cidade do Rio de Janeiro - como aluna e posteriormente professora - ao perceber que não teria oportunidades de trabalho se permanecesse na academia. Sabia que as professoras em exercício não iriam sair, e se surgisse alguma oportunidade, havia muitas interessadas entre suas amigas e colegas da turma adiantada.

Ao indagar Juliana se havia algum ponto negativo em seu trabalho uma vez que inúmeros pontos positivos haviam sido mencionados sem que eu nem houvesse perguntado -, ela disse:

Eu comentei com você hoje que eu tenho um exame. O professor de dança, especificamente o daqui, tem uma maleabilidade de horário. Muito bom, né? Mas tem essa coisa: estabelecido o horário no começo do ano, eu não posso ir ao médico à tarde. Em relação a ficar doente, a gente tem que colocar alguém no lugar. Não posso simplesmente não vir. A gente tem que cumprir o horário perfeitamente. Uma aula de uma hora, eu não posso chegar com meia hora de atraso. Então, tem essa coisa do horário, apesar de ser muito bom num ponto; no outro, a gente tem que ser muito caxias. Tem essa parte, que eu acho um ponto ruim. Fora isso, é um ambiente excelente.

Se uma professora precisar faltar, a substituição deve ser feita por outra professora da própria academia. Assim, mantém-se uma unidade e a qualidade do trabalho é assegurada. Há uma preocupação constante com o nível de excelência, e Myriam reconhece ser uma pessoa extremamente exigente consigo mesma e com as pessoas que com ela trabalham. "Se a gente pode fazer sensacional, por que a gente vai fazer só fazer excelente?" - questiona-se.

As professoras contam, portanto, com um bom ambiente de trabalho e com uma remuneração satisfatória e acima da média; mas, como contrapartida, devem ser produtivas. Além de não faltarem, elas buscam se superar para darem aulas e montarem coreografias cada vez melhores, e para que suas alunas dancem melhor a cada dia. Myriam diz saber que a perfeição é uma utopia, mas ela e suas professoras a buscam; e o balé clássico exigiria mesmo isso.

No curso que fiz na EEDMO, conforme já mencionado, o que mais me chamou atenção, logo na primeira aula, foi a forma como a professora corrigia as meninas que também faziam o curso profissionalizante. "Terrível! Horrível!" - ela gritava. Nunca havia ouvido uma professora de balé se dirigir assim às alunas. No final da aula, ela veio me perguntar se eu havia me assustado, possivelmente por saber que fora de lá as alunas não costumam ser tratadas dessa forma; e procurou se justificar: "Eu tenho que ser exigente assim, pois muitas meninas da escola [do curso profissionalizante] fazem essa aula como reforço". Essa professora, com uns 30 anos de idade, havia se formado na própria EEDMO e provavelmente se espelhava nos professores que ali teve. Para as meninas que faziam a formação profissionalizante, era preciso que fosse dispensado esse tratamento severo e rígido. Nesta aula, havia 15 meninas da 
escola e três alunas de fora. Com estas o tratamento foi bastante diferente: bem menos correções e exigências; sem gritos e broncas.

Mas, e numa academia onde há alunas que não pretendem ser bailarinas profissionais e nem mesmo professoras de balé, em que medida elas são exigidas nas aulas? Ao refletir sobre sua forma de ensinar, Myriam disse que volta e meia alguém elogia seu modo de dar aula dizendo que, ao mesmo tempo que corrige, ela valoriza o que a aluna fez de bom. Em suas palavras: "Quantas pessoas vêm fazer aula que não querem seguir a dança como carreira. Então para que atormentar a vida da pessoa que daqui a pouco vai fazer vestibular para arquitetura? Enfim, essa coisa da exigência tem que ter um limite. É o equilíbrio". Convém observar que uma exigência excessiva poderia afastar aquelas que não têm a intenção de seguir a dança como profissão, e que consistem na grande maioria das alunas, o que colocaria em risco a própria existência da academia.

Já com aquelas que trabalham como professoras de dança, a cobrança é outra. Para Geyze, por exemplo, que começou a lecionar em 2014, foi reforçada nas aulas da turma adiantadaa correção em relação à primeira posição dos braços, quando são arredondados na frente do corpo na altura do umbigo. Seus braços estavam muito altos, e Myriam disse saber que as crianças têm a tendência de levantar os braços um pouco acima do que a professora mostra, pois a veem de baixo. "Se os seus braços estiverem altos então, as crianças vão fazer aqui" - e mostrou, exagerando, na altura do pescoço. Para as professoras em geral, é recorrente a seguinte observação por parte de Myriam: "Se cada aluna fizer de um jeito, você não tem uma academia. Nós, professoras, temos que ficar atentas a isso, especialmente no balé, que é disciplina pura!". Portanto, é fundamental que as professoras se preocupem com a padronização de seus próprios movimentos, para que os transmitam a suas alunas de modo uniformizado.

Myriam normalmente fala para todas as suas alunas da turma adian$t a d a$, independentemente de serem professoras ou não: "Temos que tentar melhorar e aplicar as correções sempre. Se pensarmos 'vou deixar para a próxima semana' é uma aula perdida, que vai sendo postergada indefinidamente. No balé, o atalho não funciona. É sempre o caminho mais difícil e trabalhoso". Contudo, Myriam às vezes sente pena das alunas, e logo se recrimina: "Mas eu não posso ter pena"; o que gera certo conflito e incerteza sobre qual a melhor forma de se ensinar o balé clássico.

Em uma determinada aula, Myriam disse em relação a um passo: "Vamos fazer o grandbattement [movimento em que a perna é levantada o mais alto possível à frente, ao lado e atrás, mantendo o restante do corpo alinhado] gostoso". Ficamos na dúvida se ela se referia ironicamente ao exercício difícil que havia ensinado na aula anterior ou se era um exercício antigo, mais tranquilo e que gostávamos de fazer. "Gostoso quer dizer o que a gente gosta?" - perguntou uma aluna. "Sim" - disse Myriam. - "Pelo menos nisso eu vou aliviar hoje". E comentou que fica bem animada quando prepara uma aula nova, mas depois sente pena, ao perceber nosso cansaço. Diante disso, Bia, outra professora da EDMC, falou ter demorado duas semanas para ensinar o grandbattement de sua aula nova, por pena de suas alunas.

Bia é professora de uma turma em que eu também fiz aula, logo abaixo da adiantada, com alunas entre 15 e 19 anos.Ela é muito estimada por suas alunas devido a seu jeito meigo e doce. Mas, ainda assim, é firme nas aulas e corrige bastante. "Nada nunca está bom", disse uma aluna sua de 16 anos, após ter sido corrigida, ainda que estivesse se esforçando muito e achasse ter executado bem o passo. "Não é você que não se esforça e nem eu que sou chata. Esse tal de balé clássico, que escolhemos fazer, é que é muito difícil", respondeu a 
professora. "Sempre dá para melhorar. Às vezes nos traímos achando que já está bom e nos acomodamos. Ninguém está aqui fazendo aula para continuar do jeito que está. Todas estão aqui para melhorar, certo?’. Bia diz isso frequentemente como forma de motivação, mesmo sabendo que a maioria de suas alunas seguirá outras carreiras. Também é recorrente chamar a atenção das alunas pela conversa excessiva durante a aula. Isso costuma se fazer ainda mais necessário no retorno das férias de janeiro.

A aula transcorreu com muitos risos, num clima bem descontraído. Lembrei até que, em algumas aulas do ano anterior, a professora havia comentado que parecia que as alunas estavam na praia, por estarem relaxadas demais. $\mathrm{O}$ bronzeado que traziam em seu retorno das férias me remeteu a essa analogia. Ainda estavam em ritmo de férias, em clima de praia. Como era o primeiro dia de aula do ano, Bia disse que não iria ensinar as sequências completas de passos e que depois dificultaria os exercícios. As alunas já acharam essa versão simplificada da aula difícil e começaram a fazer piadas a respeito, logo após Bia ensinar cada sequência, ou após terem-na executado e antes da próxima ser ensinada: 'Se hoje não está difícil, imagine então na próxima semana'. Teve um exercício que ela admitiu estar difícil, ao qual se referiu como a 'pegadinha' da aula, e brincou dizendo que haveria prova $^{3}$. As meninas entraram na brincadeira: 'Ih, quem errar vai ter que voltar'. Em seguida Bia pediu: 'Falando sério agora, é para se esforçar para acertar mesmo, não é para relaxarem hoje só porque sabem que ficarão um mês fazendo esses passos'. [Nota de 3 de fevereiro de 2014].

Já ouvi Bia dizer algumas vezes que essas suas alunas deviam fazer aula um dia na turma adiantada. "Quero ver se lá vocês vão reclamar toda hora como reclamam aqui. Lá ninguém reclama". A disciplina considerada necessária ao aprendizado do balé clássico implica, assim, um esforço constante. $\mathrm{O}$ termo disciplina é entendido por minhas interlocutoras de modo semelhante à definição de Mora (2010, p. 336) - antropóloga argentina que pesquisou uma escola profissionalizante de La Plata -, como constância, concentração, compromisso e esforço. A questão aqui é avaliar qual o limite dessa disciplina num contexto que não visa à formação de bailarinas profissionais.

Geyze, que começou a dar aula de balé no início de 2014 numa turma de adulto iniciante, após ter sido aluna da EDMC por muitos anos, fez o seguinte relato quando lhe perguntei - três meses após o início de seu trabalho como professora - quais haviam sido suas expectativas:

Em relação à expectativa, eu não estava prevendo nada. Chegando lá, falei: 'Olha, eu vim pra mostrar por que eu sou apaixonada por isso e por que eu sou professora de balé'. Então, eu chegava com um carisma, mostrando que, óbvio, bailarinos de companhia, do Theatro Municipal, são absurdos, mas porque eles têm que dançar num determinado modelo. A gente está aqui para dançar para o nosso prazer, para relaxar. Então a gente vai sentir um pouquinho de dor, a gente vai ter uma proposta diferente, mas a gente também vai trabalhar com pensamento de bailarina.

É para relaxar, mas sem deixar de se concentrar para melhorar um pouco a cada aula, o que corresponderia ao pensamento de bailarina mencionado. Qual seria, então, a medida entre um trabalho sério e disciplinado - em que se exige concentração e esforço-, e um ambiente descontraído e relaxante? $\mathrm{O}$ trabalho de bailarinos em companhias, como a do Theatro Municipal do Rio de Janeiro, é uma referência. Há nas paredes das salas de aula algumas imagens de grandes bailarinas(os) em âmbito internacional. Inclusive, uma professora certa vez sugeriu a Myriam que retirasse algumas dessas fotografias, pois suas 
alunas crianças ficavam lhe perguntando se ela conseguia fazer igualmente os movimentos, se suas pernas também subiam naquela altura. De qualquer maneira, essas fotografias atuam como inspiração, ainda que a realidade seja outra.

Se dirigirmos a análise para dentro da própria academia, a exigência com a turma adiantada, em que praticamente todas as alunas são professoras, não será a mesma utilizada para lidar com uma turma de adulto iniciante, que nem mesmo dança no espetáculo de fim de ano, cujo objetivo é demonstrar em público, num teatro de Niterói, tudo o que as alunas aprenderam ao longo do ano, proporcionando para elas a vivência de uma produção completa: uma história com enredo, personagens, coreografias, cenários e iluminação. Mas, ainda que as alunas adultas iniciantes não se apresentem para um público, composto sobretudo por familiares das próprias alunas, deverão sentir um pouco de dor e se concentrar na aula.

Ocasionalmente, antes do início da aula da turma adiantada, as alunas se reúnem para assistirem a vídeos de balé em seus celulares. Numa determinada aula, viram um vídeo de uma bailarina de uma renomada companhia que fazia seis piruetas no palco, sem tocar o chão com um dos pés. Uma das alunas que também é professora da EDMC - comentou: "Enquanto isso nós fazemos uma ou duas piruetasassim", e demonstrou, exagerando o erro, afastando ainda mais os pés entre uma pirueta e outra. Isso foi feito em tom de brincadeira, em meio a risos. Continuaram vendo outros vídeos, em que piruetas eram feitas em grande quantidade e tão rapidamente que mal dava para contá-las. "Absurdo! - exclamaram. - Isso não é normal. São alienígenas!”. Uma das professoras disse, então: "Se fazendo o que eu faço, eu já sinto dor, imagina elas! Isso é o que me consola".

"Mas tem também muita gente pior do que nós" - ponderou outra professora. Afinal, na EDMC há uma grande preocupação com a qualidade do trabalho realizado, mas conforme as possibilidades de uma academia. Numaescola profissionalizante, como a EEDMO, as alunas realizam em torno de duas aulas diárias - de uma hora e meia, aproximadamente - de balé clássico, de segunda a sexta. Já na academia, mesmo na turma adiantada, são apenas três aulas por semana. E, além disso, o clima das aulas é diferente, mais descontraído, o que é reforçado pelas próprias cores do ambiente: na EEDMO, o preto e o branco predominam. Já na EDMC, as paredes são amarelas e laranjas, em tons vibrantes, alegres e convidativos, e as portas são de madeira clara com o número da sala sinalizado numa placa laranja, refletindo e acentuando, de certo modo, a descontração que seria característica do ambiente; além de funcionar como um atrativo para que novas alunas se matriculem na academia e paguem uma mensalidade.

No entanto, como já indicado, nem tudo é descontração. Um pouco antes de nos apresentarmos - como turma mais adiantada da academia -num festival de dança, Myriam nos disse que o mais importante era nos divertirmos: “Alegria e concentração!”. Era para nos divertirmos, mas mantendo a concentração para não errarmos. E, para chegarmos lá, foi preciso ensaiar muito. Uma professora de balé - que não é professora da EDMC, mas aluna de lá desde criança - me disse que suas amigas não compreendem que ela não possa faltar a um único ensaio, e caso realmente precise faltar, deve se justificar. Suas amigas a aconselham: "Você não tem que dar satisfação nenhuma, você paga muito caro para fazer aquela aula. Como assim você tem que dar satisfação porque faltou a uma única aula?". "É uma criação que a gente tem. A gente se acostuma" - ela argumenta. 
Não somos bailarinas profissionais no sentido de que se é profissional quando se recebe uma remuneração para dançar. Não só não recebemos, como pagamos - com exceção das que também são professoras da EDMC - para fazer aula na turma adiantada e dançar no espetáculo de fim de ano. Quando perguntei a Juliana se já havia tido vontade de dançar profissionalmente, ela respondeu que não, e ponderou: "O nosso grupo aqui do balé [em referência à turma adiantada], já vemos com olhares profissionais. Mas é uma academia e não uma companhia. Mas já toma meu tempo". Além de dar aula, este é mais um compromisso que assume, mais uma atividade a que não pode faltar, mais um horário a cumprir. Ela precisa ser disciplinada tanto como professora quanto como aluna da turma adiantada. É importante que dê o exemplo para suas alunas, conforme ela própria ressalta.

\section{OUTROS PARES CORRELATOS}

Haveria, assim, uma preocupação em incutir um comportamento profissional nas alunas desde crianças, tal como Juliana mencionou quando indaguei se considerava o balé mais como trabalho ou lazer:

É complicado. É bom e ruim, porque da mesma forma que é um lazer, tem a cobrança do balé clássico. E é um lazer, mas, depois daquilo, eu não dou um ponto final nesse lazer. Eu vou continuar tudo que eu aprendi lá [na turma adiantada], eu vou passar em sala, e no fim de ano a gente tem aquele encerramento que tem que mostrar o serviço. Então assim, é um lazer entre aspas. Por ser o balé, já tem uma cobrança. Então tem aquela coisa do profissional que, desde que são pequenininhas, a gente já impõe para as alunas. A disciplina do balé. Então, é uma coisa complicada esse lazer/trabalho. Mas é muito gostoso o que eu faço. Comparando com aquela minha amiga [que é administradora e sai de casa às sete da manhã e retorna às nove da noite], a gente está no trabalho, e está prazeroso ao mesmo tempo. De repente, a outra está num ambiente fechado, e que tem que cumprir aquela meta em um mês. Pelo menos, assim, a gente está fazendo aquilo mais ligado à arte. É gostoso. Então, acho que se não fossem minhas aulas, eu não ia conseguir fazer um lazer.

Rafaela, outra professora da EDMC, me contou ter começado a sentir ainda mais os efeitos dessa disciplina do balé clássico quando passou a desempenhar os papéis principais dos espetáculos de fim de ano - a dançar também como solista, e não apenas em grupo -, por volta de seus 14 anos de idade. Entretanto, numa ocasião emque ela não pôde dançar ou realizar qualquer outra atividade física, por ter machucado o joelho,diz ter sentido muita falta; o que corrobora o fato de que a atividade artística, assim como o esporte, ou outra atividade considerada lazer, geralmente é estimada em nossa sociedade como uma espécie de "válvula de escape".

De acordo com Elias e Dunning (1992), as sociedades que atingiram um nível relativamente avançado de civilização teriam uma vigorosa necessidade de sublimação, o que justificaria as inúmeras atividades de lazer. Parece haver uma emoção preexistente - entendida como pulsão ou força interna aos indivíduos - que teria sido contida com o "processo civilizatório", analisado em maior profundidade em outras obras de Elias (especialmente em ELIAS, 1994). A sublimação seria uma forma de lidar com essas emoções, mantendo sua força e ímpeto, mas sem acarretar mudanças significativas nas configurações sociais. Implica, assim, o desenvolvimento de uma agradável tensão-excitação, como sustentam os autores. O balé, bem como outras modalidades de dança, encontra-se nas fímbrias das concepções de arte, lazer e esporte. Minhas inter- 
locutoras, conforme será retomado mais adiante, privilegiam o aspecto artístico, especialmente quando desejam ressaltar que devemos realmente dançar: "Isso é dança e não simplesmente uma atividade física. É preciso sentir a música e se expressar". Por outro lado, não deixa de ser uma atividade física, e, por esse viés, aproxima-se do esporte. Como dizem algumas professoras: "Bailarina tem que suar". Além disso, é considerado lazer devido ao prazer que pode proporcionar.

Quando precisou parar de fazer aula, Rafaela percebeu que dançar não havia deixado de ser um lazer;no entanto a disciplina exigida pode fazer com que o ato de dançar deixe de ser tão prazeroso. Em suas palavras: "É um prazer diferente. É um prazer que às vezes se confunde". Devo salientar que os termos trabalho e lazer foram colocados em oposição pelo próprio modo em que elaborei a pergunta - o balé para você é mais um trabalho ou um lazer? -; e trabalho foi associado por minhas interlocutoras a algo maçante, e lazer relacionado a prazer, tal como ocorreria em outros contextos, a exemplo da pesquisa sobre o lazer no espaço doméstico de Deem (1995), que constatou que as próprias mulheres pesquisadas tinham dificuldade em definir que dimensões de sua vida eram de fato lazer, visto que isso dependia do grau de escolha e do contexto. Ainda assim, algumas pistas são fornecidas pela autora: o trabalho estaria atrelado sobretudo a obrigação e sacrifício; e o lazer a diversão e prazer. Como se dá, então, essa relação no caso em que a atividade profissional envolve arte; e quando as sociabilidades profissionais não se dissociam, a princípio, de sociabilidades lúdicas?

Contribui para essa reflexão a análise do sociólogo Campbell (2001) sobre o dinamismo da cultura ocidental moderna, que estaria assentado numa tensão entre uma "ética puritana" e uma "ética romântica" - associadas ao calvinismo e ao pietismo, respectivamente ${ }^{4}$. $\mathrm{Na}$ obra deste autor, encontramos umestudo aprofundado dos fios que prendem a experiência romântica a uma interiorização protestante. Campbell parteda argumentação de Weber (2004), procurando demonstrar que ele teria se detido demasiadamente no "puritanismo", até o final do século XVII, desconsiderando os avanços do "sentimentalismo", que teria se iniciado no interior da própria Reforma Protestante e florescido na Inglaterra do século XVIII.

\begin{abstract}
A lógica cultural da modernidade não é meramente a da racionalidade, como se expressa nas atividades de cálculo e experimentação: é também a da paixão e do sonhar criativo que nasce do anseio [...] tensão entre o sonho e a realidade, o prazer e a utilidade. É esta a fonte da harmonia com que essas tradições culturais geminadas dançam seu tango cultural no tempo, como o é das tensões conflitantes que muitos indivíduos experimentam em suas vidas diárias. Lutando para enfrentar a necessidade de proceder às trocas entre a necessidade e o prazer, enquanto procuram conciliar seus egos boêmio e burguês, os indivíduos modernos não moram somente numa 'gaiola de ferro' da necessidade econômica, mas num castelo de sonhos românticos, esforçando-se, mediante sua conduta, para transformar um no outro. (CAMPBELL, 2001, p. 318, grifos nossos).
\end{abstract}

A concepção de prazer estaria, então, permanentemente em tensão. Campbell analisa também a relação entre prazer e dor, cuja associação pode ser pensada em termos da satisfação adiada e interrompida, de forma queos sacrifícios maximizariam o prazer a ser consumido posteriormente ${ }^{5}$. Wulff, em seu estudo de grandes companhias de balé recorre à categoria prazer para refletir sobre a permanência do balé clássico até os dias atuais, a despeito do advento da dança moderna e contemporânea. A autora sustenta que "com a habilidade de mover e manipular seus corpos de modos bem mais elaborados, os bailarinos podem sentir um prazer profundo" (WULFF, 2008, p. 525), sendo que, para 
conseguir realizar esses tipos de movimentos, é necessário um longo e constante treinamento que implica muito sacrifício e dor.

É consenso entre minhas interlocutoras que até mesmo as principais bailarinas de renomadas companhias, supostamente dotadas das condições fisicas valorizados no balé, precisam se esforçar muito diariamente. É imprescindível que tenham disciplina para fazerem aulas diárias, além dos inúmeros ensaios. Todo esse trabalho de moldar o corpo remete a uma concepção mecanicista, ao corpo entendido como máquina, passível de ser manipulado e adestrado a partir de regras e princípios; numa escala mais ampla, remete-se ao "polo iluminista" da tensão. Mora (2010) sublinha que a isso se soma a influência do "romantismo", a concepção de leveza da bailarina; e sustenta que as duas correntes, a princípio opostas, coexistem no balé por compartilharem o ideal de se afastar da animalidade e da materialidade dos corpos, em busca de um ideal de perfeição. Todo o labor empreendido pela bailarina não deve transparecer aos olhos do público; e é esse grande esforço altamente racionalizado, despendido para o domínio da técnica, que possibilita a execução suave de movimentos sobre-humanos e extraterrenos.

Convém chamar atenção para o fato de que, como profissional da dança - ainda que não se seja bailarina profissional -, pode-se enfeitar os movimentos, o que é inclusive valorizado. Mas somente depois que se tem um bom domínio técnico. É uma respiração do braço, uma intenção diferente da cabeça; é sentir a música e dançar com emoção. A respeito da relação entre técnica e emoção, de acordo com Mora (2010, p. 414), "se sustenta que a internalização da técnica é o que permitirá a expressão de emoções, isto é, se condiciona à incorporação completa da técnica a possibilidade de deixar de pensar nela para expressar-se e desfrutar".

"O artístico é o que mais conta para o público. Por isso, não adianta fazer tudo certo tecnicamente, apesar da técnica ser muito importante, e ficar como um robô. É preciso expressar emoção" - disse Myriam numa aula. A dança sem esse viés artístico seria, assim, uma mera atividade física, de acordo com minhas interlocutoras. Por outro lado, é preciso ter cuidado para não se adquiriremvíciosao expressarem emoções; para que, por exemplo, a respiração do braço num determinado passo não resulte sempre num braço alto demais, pois as alunas que ainda estão no início de seu aprendizado da técnica copiarão isso. Pode-se aludir à "imitação prestigiosa" de que fala Mauss em seu renomado texto sobre as técnicas do corpo. "A criança, como o adulto, imita atos bem-sucedidos que ela viu serem efetuados por pessoas nas quais confia e que têm autoridade sobre ela" (MAUSS, 2003, p. 405). Daí o aumento da responsabilidade da professora de balé, que precisa transmitir a técnica de modo apropriado, e, para tanto, é importante ter disciplina. Mas, como aluna de balé da turma adiantada, essa professora deve ir além da técnica, até mesmo para que a dança se configure como arte, o que proporcionaria um maior prazer.

Segundo Elias (1995), as noções de fluxo-fantasia, regularidades do material e consciência do artista devem ser entendidas em conjunto. Mozart teria chegado ao pináculo da criação artística porque, aliado ao fluxo-fantasia, tinha um imenso controle das regularidades do material e uma consciência de artista altamente desenvolvida. O conceito de regularidades do material de Elias aproxima-se da noção de técnica. Quanto maior a incorporação da técnica ou quanto maior o grau de implementação da informação no corpo, maior o controle das regularidades do material.Dessa forma, o domínio das regularidades do material implica uma incorporação da técnica para criar de maneira comunicável. Essa possibilidade é o que, segundo Elias, diferencia a fantasia do esquizofrênico da fantasia do artista. 
Essa fantasia, por sua vez, colocaria em relevo a dimensão do lazer, que, segundo Deem (1995), se opõe a trabalho justamente pela associação a prazer, e não a obrigação. Por outro lado, cabe retomar a constatação de que essa sublimação pelo lazer, esporte e arte (sendo que a dança poderia se enquadrar nas três classificações, conforme já foi visto) favorece a manutenção das configurações sociais construídas pelo trabalho e pela disciplina. Wulff (2008) justifica, assim, a permanência do balé clássico, a despeito de toda a disciplina exigida e da dor implicada, pelo prazer que também proporciona. No caso dos bailarinos profissionais, a dor seria maior, mas o prazertambém - um prazer associado à execução de movimentos extremamente difíceis. No contexto por mim analisado, esse tipo de prazer é menor, mas compensado por um outro prazer proporcionado pelo clima mais descontraído.

Entre os valores românticos atrelados ao balé clássico, estariam, então, o prazere a leveza associada a uma dimensão sublime. Mas que prazer - um "prazer diferente", conforme já citado - é esse que Rafaela diz ter voltado a sentir quando retomou as aulas de balé clássico? Alguns meses depois de nossa conversa, ela postou em uma rede social um vídeo em que aparecia fazendo um exercício de salto na aula, acompanhado do seguinte texto de sua autoria: " $\mathrm{E}$ ali naquele segundo dançante eu sou ar, sou chão, sou rainha, princesa, fada, sou triste, sou feliz, muito feliz, superação, e pé no chão". Ela é ar e chão, tristeza e felicidade. Mais felicidade do que tristeza; mas, ainda assim, a dualidade se faz presente. A felicidade se associa à superação, que a leva a ser uma rainha, princesa, fada, ou seja, é conduzida a uma dimensão extraterrena; mas sem que se desvincule totalmenteda realidade, visto que mantém um pé no chão, a despeito de seus saltos.

Como enfatizou a professora e aluna de balé Juliana, somos cobradas a cada aula; precisamos ser disciplinadas para progredirmos no aprendizado dessa dança. Por outro lado, além do prazer que pode ser obtido com cada conquista e superação, também rimos e nos divertimos.É diferente, portanto, do que vivenciei na EEDMO - com intuito profissionalizante -, onde as alunas são tratadas de forma rígida e severa, e dificilmente é feita alguma brincadeira na aula.

A exemplo do que faz Duarte (2006), ao sinalizar que o "romantismo" é o contraponto ou o termo reativo da "inarredável tensão entre iluminismo e romantismo" - se considerarmos a "cultura ocidental moderna" em termos abrangentes -, qual seria, no caso da turma adiantada da EDMC, o valor englobante? É difícil precisar qual dos termos - disciplina ou descontração - estaria em condição desfavorecida. Por isso, procurei sugerir diferenças em relação a outros contextos de ensino da dança: na EEDMO,cujo foco é a formação de bailarinas profissionais, haveria mais disciplina; e na turma de adulto iniciante de Geyze (na própria EDMC),em que não há nenhuma intenção por parte das alunas de trabalharem com o balé, mais descontração e relaxamento.

\section{CONSIDERAÇÕES FINAIS}

Cabe pontuar que o presente texto não teve por foco os movimentos dançantes ou, até mesmo, a dança em si; mas as dinâmicas de sociabilidade que se produzem no espaço de uma academia de dança. De todo modo, conforme coloca Kaeppler (2013, p. 109), "a contribuição possível da dança numa perspectiva antropológica reside no que a dança nos revela sobre a sociedade e sobre o comportamento dos homens que engendraram os sistemas culturais diversos".

Procurei reforçar, dessa forma, como é uma questão crucial no contexto da Escola de Dança Myriam Camargo a relação entre disciplina e des- 
contração, termos que mais apareceram no discurso das professoras de balé clássico; e entre outros pares correlatos, como trabalho e lazer, dor e prazer, técnica e emoção. Para finalizar, será abordada um pouco mais essa temática ao colocá-la em diálogo com a noção de "negociação da realidade", conforme analisada por Velho:

A própria ideia de negociação implica o reconhecimento da diferença como elemento constitutivo da sociedade. Como sabemos, não só o conflito, mas a troca, a aliança, e a interação em geral, constituem a própria vida social através da experiência, da produção e do reconhecimento explícito ou implícito de interesses e valores diferentes. (VELHO, 2003, p. 21-22, grifo do autor).

Na presente pesquisa, os diferentes valores trazidos à tona, pelos sinais empíricos, foram observados em referência à cultura ocidental moderna e à "inarredável tensão entre iluminismo e romantismo" que lhe seria constituinte (DUARTE, 2006), na medida em que os dados de campo por mim construídos, na interação com minhas interlocutoras, conduziram à análise de diferentes facetas dessa "tensão". O fato de não se tratar de um contexto profissionalizante ou profissional do balé clássico parece explicitar a dimensão de "negociação da realidade". É evidente que um estudo aprofundado desses outros contextos traria outras nuances. De todo modo, pelos trabalhos consultados (WULFF, 1998; HOPPE, 2000; MORA, 2010; RUIZ, 2010) e pela experiência de frequentar aulas de que meninas do curso profissionalizante da EEDMO também participavam, pareceu-me que, nesse tipo de contexto, há menos dúvidas quanto ao modo de agir de uma professora de balé clássico: é fundamental ser rígida e impor disciplina. Todas as alunas são consideradas dotadas de condições físicas, o que propicia uma maior homogeneidade à turma, em comparação com as academias de dança, onde não há uma prova de seleção; e podem ser notadas, portanto, diferenças significativas em relação aos objetivos de cada aluna, o que tornaria mais complexo o "jogo de negociação da realidade".

Conforme foi visto, Myriam - proprietária da EDMC - questiona-se até que ponto cabe exigir de uma aluna que tem por objetivo prestar vestibular para outras áreas, bem diferentes da dança. É preciso ter em vista que a academia, como uma empresa que é, precisa ter alunas para se sustentar, e uma cobrança excessiva poderia afugentá-las. Um clima descontraído, atrelado à produção de relações de família, contribui para mantê-las na academia.Por outro lado, é preciso que haja certa disciplina, para que o aprendizado do balé possa se concretizar, até mesmo no caso de alunas adultas iniciantes. Nas aulas da turma adiantada, a disciplina adquire maior importância, especialmente para aquelas que, além de alunas, são também professoras. Mas, ainda assim, o clima é descontraído eestá longe da disciplina e do esforço exigidos de bailarinos profissionais.

A intenção foi, portanto, apresentar outra forma de vivência do balé clássico, que normalmente é ofuscada pelas experiências associadas a contextos profissionais. Esta pesquisa do balé clássico - ao lado de outras citadas ao longo deste texto -, ao trazer à tona diferentes facetas da "inarredável tensão", permite aventar que tensões estarão permanentemente em jogo e a realidade será constantemente negociada, nas relações intersubjetivas, na interação com diferentes valores e interesses, conforme os campos de possibilidades. Por outro lado, evidencia as peculiaridades de cada caso, caras ao trabalho etnográfico, e indica o potencial de estudos comparativos de diferentes contextos do balé clássico - não apenas em relação à questão da profissionalização, mas também no que tange a camadas sociais e localidades -, de outras modalidades de dança, e também do lazer e do esporte, o que poderá ser desenvolvido em trabalhos futuros. 


\section{NOTAS}

${ }^{1}$ A despeito de se autodenominar "escola de dança", academia é o termo mais utilizado pelas alunas e professoras para se referir à Escola de Dança Myriam Camargo, ainda que o termo escola também seja eventualmente empregado. Cabe pontuar que as menções a balé - simplesmente - ao longo deste artigo, por mim e por minhas interlocutoras, referem-se ao balé clássico.

${ }^{2}$ As expressões e categorias utilizadas especificamente, ou com um sentido particular, no universo pesquisado serão grafadas em itálico ao longo do texto.

${ }^{3}$ Não há nenhum tipo de avaliação formal. Caso a aluna esteja com dificuldade para acompanhar a turma, a professora, após consultar a diretora da academia, conversa com ela e sua mãe. Pode ser recomendado que repita o nível ou então que avance e continue fazendo também, como reforço, a aula do nível em que teve dificuldade. Já na EEDMO, além da concorrida prova de ingresso, as alunas são avaliadas em todas as aulas, com a atribuição de notas, e submetidas a uma prova no final de cada ano.

${ }^{4}$ Essa relação pode ser evocada utilizando-se outros termos. Duarte (2012, p. 419) se refere ao "par iluminismo / romantismo, considerado suficientemente elástico para abrigar uma infinidade de variações históricas e nuances ideológicas no período dito 'moderno' da cultura ocidental".

5 "O desejo dominante do hedonista é o de estimular experiências, e a própria dor pode ser um meio extremamente eficaz de proporcionar precisamente tal excitação agradável". (CAMPBELL, 2001, p. 95). A análise deste autor procura demonstrar como o hedonismo moderno se ancora numa busca qualitativa pelo consumo de um prazer de intensidade sempre maior, sendo todos os atos prazeres potenciais.

\section{REFERÊNCIAS}

ABREU, Fernanda Ferreira de. Entre a aula e o palco: carreiras de professoras de balé clássico na cidade de Niterói. Tese. (Doutorado em Antropologia Social) Departamento de Antropologia Social, Museu Nacional, Universidade Federal do Rio de Janeiro, Rio de Janeiro, 2016.

. Uma etnografia do balé clássico: escolhas, angústias e vivências iniciais. Intratextos. v. 7, n. 1, p. 69-89, 2015.

CAMPBELL, Colin. A ética romântica e o espirito do consumismo moderno. Rio de Janeiro: Rocco, 2001.

DAMATTA, Roberto. O ofício de etnólogo, ou como ter anthropological blues. In: NUNES, Edson de Oliveira (Org.). A aventura sociológica. Objetividade, paixão, improviso e método na pesquisa social. Rio de Janeiro: Zahar, 1978.

DEEM, Rosemary. Leisureandthehousehold. In: JACKSON, Shaun; MOORES, Steve (eds.). The politicsofdomesticconsumption. CriticalReadings. New York, London: Prentice Hall \&HarvesterWheatsheaf, 1995. p. 137-150.

DUARTE, Luiz Fernando Dias. Formação e ensino na antropologia social: os dilemas da universalização romântica. In: GROSSI, Miriam Pillar; TASSINARI, Antonella;RIAL, Carmen (Orgs.). Ensino de Antropologia no Brasil: formação, práticas disciplinares e além fronteiras. Blumenau: Nova Letra, 2006.

. O paradoxo de Bergson. Diferença e holismo na antropologia do ocidente. Mana: estudos de antropologia social. v. 18, n. 3, p. 417-448, 2012.

ELIAS, Norbert.Mozart, sociologia de um gênio. Rio de Janeiro: Zahar, 1995. . O processo civilizador. Rio de Janeiro: Zahar, 1994.

; DUNNING, Eric. A busca da excitação. Lisboa: Difel, 1992.

HOPPE, Sigrid. Produção corporal da mulher que dança. Dissertação. (Mestrado em Antropologia) Departamento de Antropologia, Universidade Federal Fluminense, Niterói, 2000. 
KAEPPLER, Adrienne. A dança segundo a perspectiva antropológica. In: CAMARGO, Gisele (Org.). Antropologia da Dança I. Florianópolis: Insular, 2013.

MAUSS, Marcel. As técnicas do corpo. In: Sociologia e antropologia. São Paulo: Cosac Naify, 2003. p. 399-423.

MORA, Ana Sabrina. El cuerpoenladanza desde laantropología. Prácticas, representaciones y experiencias durante laformaciónendanzasclásicas, danzacontemporánea y expresión corporal. Tese. (Doutorado em Antropologia) Facultad de CienciasNaturales y Museo,Universidad Nacional de La Plata, La Plata, 2010.

RUIZ, Sandra. Partituras delcuerpo: etnografía sobre bailarines de puntas y media puntasenlaciudad de Córdoba. Dissertação. (Mestrado em Antropologia) Facultad de Filosofía y Humanidades, Universidad Nacional de Córdoba, Córdoba, 2010.

VELHO, Gilberto. Projeto e metamorfose: antropologia das sociedades complexas. Rio de Janeiro: Zahar, 2003.

WACQUANT, Loïc. Corpo e alma: notas etnográficas de um aprendiz de boxe. Rio de Janeiro: Relume-Dumará, 2002.

WEBER, Max. A ética protestante e o "espírito" do capitalismo. São Paulo: Companhia das Letras, 2004.

WULFF, Helena. Ballet across borders: career and culture in the world of dancers. Oxford: Berg, 1998.

. Ethereal expression: paradoxes of ballet as a global physical culture.

Ethnography. v. 9, n. 4, p. 518-535, 2008. 